\title{
Kernos
}

Revue internationale et pluridisciplinaire de religion grecque antique

25 | 2012

Varia

\section{Theological Etymologizing in the Early Stoa}

\section{Mikolaj Domaradzki}

\section{OpenEdition}

\section{Journals}

\section{Electronic version}

URL: http://journals.openedition.org/kernos/2109

DOI: 10.4000/kernos.2109

ISSN: 2034-7871

\section{Publisher}

Centre international d'étude de la religion grecque antique

\section{Printed version}

Date of publication: 26 October 2012

Number of pages: 125-148

ISSN: 0776-3824

\section{Electronic reference}

Mikolaj Domaradzki, « Theological Etymologizing in the Early Stoa », Kernos [Online], 25 | 2012, Online since 20 November 2014 , connection on 15 October 2019. URL : http://journals.openedition.org/ kernos/2109; DOI : 10.4000/kernos.2109 


\title{
Theological Etymologizing in the Early Stoa*
}

\begin{abstract}
The present article aims to show that etymologizing was an integral part of Stoic theology. The Stoics' pantheistic and hylozoistic view of the cosmos made it natural for these thinkers to use etymology for the purpose of discovering the diverse manifestations of God in the universe. Accordingly, the main thesis of the paper posits that, within Stoicism, etymology was not so much the study of the history of words, but rather that of how God develops and reveals Himself in the various phenomena of our world. Inasmuch as studying the names of the gods was for the Stoics tantamount to seeking God, etymology played a threefold function in Stoicism: firstly, it was a means to honor God; secondly, it was a way of interpreting poetry; and finally, it was also a tool for transforming one's own existence. Consequently, the present article investigates the theological, the allegorical and, lastly, the existential dimension of Stoic etymologizing.

Résumé : Le but de cet article est de démontrer que l'étymologie faisait intégralement partie de la théologie stoïcienne. Suivant leur conception panthéiste et hylozoiste du cosmos, les stoïciens utilisaient l'étymologie pour découvir diverses manifestations de Dieu dans l'univers. Ainsi, la thèse principale de cet article est de montrer que, dans le stoïcisme, l'étymologie était moins une étude sur l'histoire des mots que l'étude de la façon dont Dieu se développe et se manifeste à travers divers phénomènes de notre monde. Attendu que pour les stoïciens le fait d'étudier les noms des dieux équivalait à rechercher Dieu, l'étymologie jouait un triple rôle : premièrement, elle était un moyen de rendre un culte à Dieu; deuxièmement, elle était une manière d'interpréter la poésie; et, enfin, elle était un outil de transformation de sa propre existence. Par conséquent, cet article se veut une recherche sur la dimension théologique, allégorique et existentielle de l'étymologie stoïcienne.
\end{abstract}

\section{Introduction}

The purpose of the present paper is to examine the pivotal role that etymology came to play in the early Stoics' original theology. Although, at first sight, many a Stoic etymological interpretation may give the impression of being inconsistent, irreconcilable and even irreverent, the article will argue that through their etymologizing the Stoics did not seek to eradicate the then religion by turning it into physics. Rather, their intention was to reinterpret the existing religious beliefs so as to pave thereby the way for what they took to be genuine religiousness.

\footnotetext{
${ }^{*}$ I would like to thank the anonymous reviewer for his insightful and inspiring suggestions.
} 
In order to be properly understood, Stoic etymologizing needs to be placed in the context of the philosophers' complex physics (which the Stoics assumed to include theology). In nuce, the Stoics' account of reality is organicistic, vitalistic, hylozoistic, and pantheistic: the world is a living organism that is steered by a vital force, all matter possesses life, and the whole of the universe is identical with God (see more on this below). The Stoics' pantheistic view of God as an omnipotent force that pervades the cosmos and adopts various appellations in accord with God's distinct powers, justified using etymology as a tool for deciphering the manifold manifestations of one and the same Deity. ${ }^{1}$ While etymologizing enabled, thus, the early Stoics to treat the particular names and epithets of the gods as diverse expressions of one God, etymology became in this way an encounter with Divinity through language: the specific names of the gods and goddesses transpired to essentially light up the divinity of God-Cosmos from different sides.

Obviously, it has to be emphasized that the extant testimonies on the early Stoics' etymologizing are so fragmentary and mediated that it is hardly possible to present anything like a definitive and indisputable account thereof. Yet, while the indirectness of the sources precludes any conclusiveness, the present article will aim to show that numerous interpretative difficulties are dissolved, when the early Stoics' etymologizing is read as an attempt to seek God in the aforementioned sense. In order to bring forth the functions of Stoic etymologizing the paper has been structured in the following manner: section 1 discusses ancient opposition to Stoic hermeneutics, section 2 focuses on the theological dimension of Stoic etymologizing, section 3 touches upon its allegorical dimension and section 4 deals with its existential dimension. Naturally, the account of Stoic etymologizing

1 The idea that the particular gods and goddesses are but the revelations of one and the same God is the hallmark of Stoic pantheistic theology. From the perspective of our considerations the most important assumption of the early Stoics' hermeneutics is that "pour un Stoïcien, les dieux ne sont pas des éléments ou des forces naturelles, mais la manifestation de la raison divine dans ces éléments, dans ses forces naturelles", L. BRISSON, Introduction à la philosophie du mythe. 1. Sauver les mythes, Paris, 1996, p. 69. The same point is made by Goulet, who explains that in the Stoics' "nouvelle théologie" the traditional gods are nothing but symbols or allegories of "les forces divines qui expriment à travers toutes choses la Raison universelle", R. GOULET, "La méthode allégorique chez les Stoïciens", in G. Romeyer Dherbey, J.B. Gourinat (ed.), Les Stoïciens, 2005 , p. 111. While the present paper builds on the assumption that for the Stoics all deities are merely expressions of the ultimate Divinity (referred to interchangeably as God, Zeus, Logos, Pneuma, Nature, etc.), such an account of Stoic theology emerges in one way or another from the following works: F. Buffière, Les Mythes d'Homère et la pensée grecque, Paris, 1956, p. 141-146; M.L. Colish, The Stoic Tradition From Antiquity to the Early Middle Ages, Leiden, 1985, p. 23-27; J. Whitman, Allegory. The Dynamics of an Ancient and Medieval Technique, Cambridge, 1987, p. 31-38; C. BlÖNnigen, Der griechische Ursprung der jüdisch-hellenistischen Allegorese und ibre Rezeption in der alexandrischen Patristik, Frankfurt am Main, 1992, p. 22-23; K. AlgrA, "Stoic Theology", in B. INwood, The Cambridge Companion to the Stoics, Cambridge, 2003, p. 165-170 and P.T. STRUCK, Birth of the Symbol: Ancient Readers at the Limits of Their Texts, Princeton, 2004, p. 135-141. 
that is put forward here covers only some facets of this cultural phenomenon and, consequently, does not purport to be exhaustive.

\section{Ancient opposition to Stoic hermeneutics}

Apart from the numerous controversies surrounding the credibility of many testimonies, one may level at least two fundamental objections against the first Stoics' etymological analyses: on the one hand, the philosophers may be accused of offering contradictory and, therefore, self-cancelling explanations, and, on the other hand, the Stoics may be charged with blasphemy, since the various etymological interpretations of the gods put forward by the philosophers appeared to the then mentality as designed to abolish traditional religion. Let us look at some ancient articulations of these criticisms.

First of all, the Stoics would often propose etymological interpretations that could easily be dismissed as mutually exclusive. Here, one might for example cite Macrobius who relates that Cleanthes, on the one hand, identified the sun with Apollo, deriving the name from the fact that the god "rises at different times at

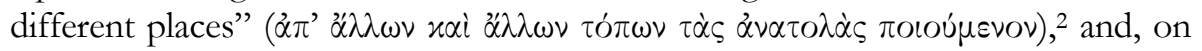
the other, the philosopher equated the sun with Dionysus, deriving the name from the verb "to complete" ( $\delta \iota \alpha v \dot{\sigma} \sigma \iota)$ and arguing that "in its daily course from rising to setting the sun completes the circle of the heavens, making the day and the night" (cotidiano impetu ab oriente ad occasum diem noctemque faciendo caeli conficit cursum). ${ }^{3}$ Cleanthes' identification of the sun with both Apollo and Dionysus might be regarded as inconsistent and contradictory, upon which his etymologizing could be labelled as self-refuting.

Secondly and relatedly, the Stoics would also frequently present several alternative etymologies for one and the same word. While this can be most spectacularly observed in Cornutus, ${ }^{4}$ with regard to the first Stoics, we could again quote Macrobius who reports Chrysippus to have offered two explanations of Apollo's name. On the assumption that this god's name comprises a privative alpha, the philosopher derived the name either from the fact that the sun "consists of not

\footnotetext{
2 SVF I, 540. With the exception of Cleanthes' hymn (see infra, note 30) and Heraclitus (see infra, note 77), all translations are mine. However, when trying to make my renditions as true to the Greek original as possible I consulted two very good English translations: A.A. LONG, D.N. SEDley, The Hellenistic Philosophers. 1. Translations of the Principal Sources with Philosophical Commentary, Cambridge, 1987, p. 158-437 and B. InwoOD, L.P. GERSON, Hellenistic Philosophy. Introductory Readings, Indianapolis, 1997, p. 103-260.

3 SVF I, 546. Several of the Stoics' exegeses that are analyzed here can also be taken as illustrating the philosophers' keen interest in the genesis of conventional religion. See in this respect M. DomARADZKI, "From Etymology to Ethnology. On the Development of Stoic Allegorism", Archinum bistorii filozofii i myśli społecznej 56 (2011), p. 81-100.

${ }^{4}$ Throughout the paper I cite the text from: Cornuti theologiae Graece compendium, ed. C. LANG, Leipzig, 1881.
} 


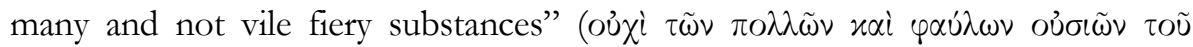

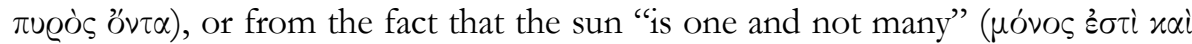
oủxi $\pi \circ \lambda \lambda o i) .{ }^{5}$ Again, one could point out that offering several alternative etymologies is tantamount to offering contradictory etymologies, since no criteria for distinguishing between right and wrong interpretations are provided. Thus, from a purely logical point of view many Stoic interpretations appear to be at odds with one another both with respect to the identity of the referent in question and with respect to the etymology of its name.

In the light of all that has been said so far, it should come as no surprise that the Stoics' etymological interpretations were frowned upon already in antiquity and that the philosophers were often charged with presenting conflicting and thereby self-refuting interpretations. Such criticisms of Stoic hermeneutics can easily be found in thinkers who actually did embrace Stoicism and in authors who flatly repudiated it. Thus, the Stoic Seneca rejects the early Stoics' etymologizing, pointing precisely to the philosophers' inability to offer any criteria for establishing what a correct interpretation should look like. When commenting on Chrysippus' account of the Graces, Seneca diagnoses that these names are interpreted just "as it suits everyone" (prout cuique visum est). ${ }^{6}$ For Seneca, Chrysippus' etymologizing is not only a meaningless and totally arbitrary mumbo-jumbo, but it is also a classical straw man. Hence, having refused to acknowledge that it is at all "relevant" (ad rem [...] pertinere) what names were given by Hesiod to the three Graces, Seneca castigates Chrysippus mercilessly for "filling his whole book with such absurdities" (totum librum suum his ineptiis replet)..$^{7}$ From Seneca's point of view, etymologizing can be used in support of virtually any argument and, therefore, its probative power is nil.

A very similar criticism is offered by the Middle Platonist Plutarch who, interestingly enough, is uncompromisingly critical of etymologizing and allegorizing Homer in his How the Young Man Should Study Poetry, but who, nevertheless, does interpret Egyptian myths allegorically in his On Isis and Osiris. ${ }^{8}$ Thus, Plutarch admonishes that one ought to "refrain from the puerility $(\pi \alpha \iota \delta \iota \dot{\nu} \nu)$ of Cleanthes" who evidently "resorts to a mock seriousness" ( $\alpha \alpha \tau \varepsilon \varrho \omega \nu \varepsilon u ́ \varepsilon \tau \alpha \iota)$, whereas he only "pretends to be interpreting" ( Homer. ${ }^{9}$ In a similar vein, Plutarch assesses the hermeneutical activity of Chrysippus, who is characterized as "frequently petty" ( $\pi \circ \lambda \lambda \alpha \chi O \tilde{\nu} \gamma \lambda i ́ \sigma \chi \varrho \circ \varsigma)$,

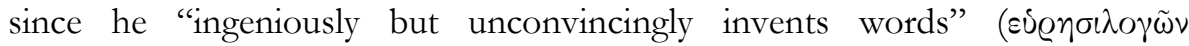
$\dot{\alpha} \pi \imath \dot{\alpha} \nu \omega \varsigma)$ when interpreting the poet. ${ }^{10}$ Similarly to Seneca, Plutarch refuses

\footnotetext{
5 SVF II, 1095.

${ }^{6}$ Sen., Benef. I, 3, 6 (= SVF II, 1082).

${ }^{7}$ Sen., Benef. I, 3, 6-8 (= SVF II, 1082).

${ }^{8}$ See infra, note 95.

9 Plu., De aud. poet., 31d-e (= SVF I, 535).

${ }^{10} \mathrm{Plu}$., De and. poet., 31e (= SVF II, 1062).
} 
then to acknowledge the validity of etymological interpretations. Hence, for both these thinkers, Stoic etymologizing gives an impression of being an ad hoc venture: thoroughly devoid of any standards and thereby self-contradictory. ${ }^{11}$

Still, things look even worse from a theological point of view, as many a Stoic interpretation seems prima facie blasphemous. After all, numerous accounts of the gods put forward by the philosophers entail a transformation of religion into a pantheistic physics which threatens to abrogate the official creed. ${ }^{12}$ Generally speaking, the Stoics identify God with the world and assume that the whole of reality can be derived from this all-encompassing God-Universe. ${ }^{13}$ While this pantheism is already to be found in Zeno who identified "the substance of God"

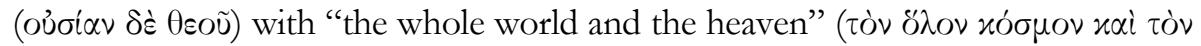
oủ @avóv), ${ }^{14}$ the idea was embraced by other Stoics who also equated the cosmos with God. ${ }^{15}$ Yet, for the Stoics God is not only identical with the world. The philosophers asserted also that "God permeates the whole of reality" ( $\delta \iota \dot{\alpha} \pi \dot{\alpha} \sigma \eta \varsigma$

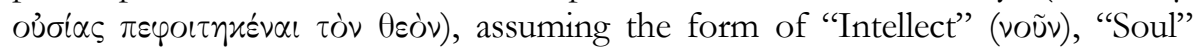

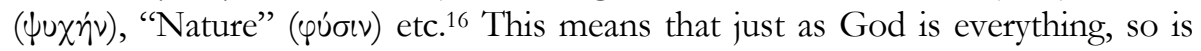
He in everything. Accordingly, God is the principle that flows through all matter, thereby animating and administering it.

While this principle adopts such appellations as Intellect or Nature, it is also the basis of Stoic vitalism, since the philosophers regard God as the ultimate force that powers the cosmos: all life in the universe is brought about and maintained by the self-determining and self-evolving vital force which the Stoics refer to as the Pneuma. Thus, the philosophers make it clear that "the whole reality is unified and sustained by the Pneuma which pervades it all" ( $\dot{\eta} \nu \tilde{\omega} \sigma \theta \alpha \iota \mu \dot{\varepsilon} \nu$

\footnotetext{
11 Thus, it is clear that the detractors of Stoic etymologizing would embrace the following diagnosis: "Dans certains cas, l'étymologie n'est pas seulement multiple, elle est contradictoire", M. Dixsaut, Platon et la question de la pensée, Paris, 2000, p. 172. While the opponents of Stoic hermeneutics seem to have assumed that offering alternative etymologies amounts to offering contradictory etymologies, the assumption was hardly a prevailing one: ancient advocates of etymology would rather frequently assume that the more options a given etymology puts forward, the more valuable it is, since the alternatives are complementary rather than contradictory. For an excellent discussion of this point see D. SEDLEY, Plato's Cratylus, Cambridge, 2003, p. 35-37. This assumption, as will be seen, permeates Stoic hermeneutics. Cf. also infra, note 46.

12 This phenomenon is by no means limited to the Stoics, as it is closely intertwined with the rise of ancient allegoresis in general. I discuss the complex relationship between allegorical interpretation and the resulting rationalization of religion in: M. DOMARADZKI, "Allegoresis in the Fifth Century B.C.", Eos 97 (2010), p. 233-248 and "Theagenes of Rhegium and the Rise of Allegorical Interpretation", Elenchos 32 (2011), p. 205-227.

13 Such a form of pantheism, blended with certain acosmism though, has been embraced by Plotinus. See M. DomARADZKI, "Plotinus' Rejection of Supernaturalism", in G. ARABATZIS (ed.), Studies on Supernaturalism, Berlin, 2009, p. 107-125.

14 SVF I, 163.

15 SVF II, 526 and 528.

16 SVF I, 158.
} 
نं The idea that God is the creative power that governs the whole of the world has the following implications: first of all, characterizing God as anima mundi means rejecting the idea that God is a person; secondly and relatedly, such an account of God makes it necessary for the Stoics to somehow account for the existence of the whole Pantheon of traditional Greek deities. The upshot is, then, that in Stoicism all the conventional anthropomorphic gods and goddesses become reduced to various manifestations of the divine generative force that the Stoics equate with their God. ${ }^{18}$ Let us quote some examples. If the Stoics in general

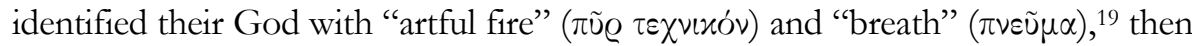
this view of God as fiery breath appears to be present, for example, in Cleanthes'

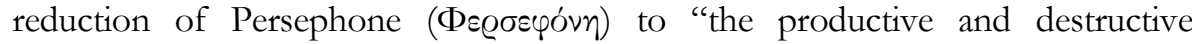
Pneuma" ( $\varphi \varepsilon \varrho o ́ \mu \varepsilon v o v ~ x \alpha i ~ \varphi o v \varepsilon v o ́ \mu \varepsilon v o v ~ \pi \nu \varepsilon \tilde{u} \mu \alpha) .{ }^{20}$ In a similar vein, the founder of Stoicism reduced Hesiod's X'́os to water, ${ }^{21}$ whereas the Cyclopes became merely

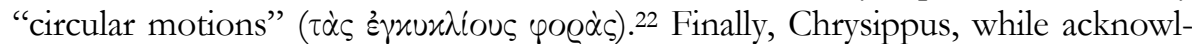
edging the divinity of Zeus, reduced, nevertheless, Hera to "matter" (í $\lambda \eta) .{ }^{23}$

Interpretations such as these exposed the Stoics to the charge that the philosophers' exegetical activity was aimed at rescinding religion. This is clear in the tirade that the Epicurean Velleius launches against the Stoics in Cicero's On the Nature of the Gods. Sparing none of the first Stoics, Velleius flatly repudiates all of their hermeneutical activity, pointing precisely to the unholy and ungodly implications of Stoic pantheism. Thus, Zeno is disparaged for identifying Divinity with "the law of nature" (naturalem legem), ${ }^{24}$ for equating God with aether, ${ }^{25}$ and for "interpreting" (interpretatur) Hesiod's Theogony in such a manner that "the

17 SVF II, 473.

18 As Buffière observes: "Ils [scil. Les dieux de la religion populaire] se dépouillent de leur forme humaine, de leur personnalité, pour devenir en quelque sorte des fragments de miroir reflétant tous le même dieu, dans l'infinie variété de ses aspects", Buffière, o.c. (n. 1), p. 153.

19 SVF II, 1027. Cf. infra, note 32.

20 SVFI, 547.

21 SVF I, 103. While a very similar explanation is to be found in Cornutus $(28,8)$, I wholeheartedly agree with the diagnosis that not "all unattested etymological explanations in a later Stoic author like Cornutus can be ascribed to Zeno", K. ALGRA, "Comments or Commentary? Zeno of Citium and Hesiod's Theogonia”, Mnemosyne 54 (2001), p. 566. Still, what is important for my considerations here is that they can be taken as belonging to the Stoics' general repertoire. Let us recall that the purpose of the present paper is to give an overview of how the Stoics made their religious use of etymology. As the article is concerned with the Stoics in general, it confines itself to establishing that a given etymological explanation and the related interpretation may be characterized as Stoic. That is also why the testimony of Cornutus is often cited here as evidence supporting the Stoic character of the particular interpretations.

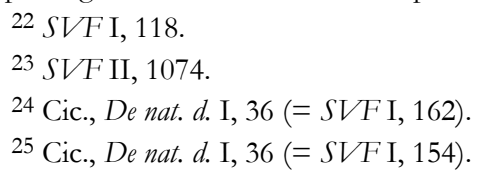


established notions of the gods are completely abolished" (tollit omnino usitatas perceptasque cognitiones deorum). ${ }^{26}$ Then, Cleanthes is berated for "attributing all divinity to the stars" (divinitatem omnem tribuit astris), and for identifying God with either "this very world" (ipsum mundum), or with "the mind and spirit of universal nature (totius naturae menti atque animo), or, finally, with aether. ${ }^{27}$ Lastly, Chrysippus is decried for deifying virtually everything - so excessively as to the point of absurdity. Hence, the philosopher is censured for, among others, firstly placing the divine power "in reason" (in ratione), and "in the spirit and mind of universal nature" (in universae naturae animo atque mente), then, for identifying God with "the very world and the universal effusion of its spirit" (ipsumque mundum [...] et eius animi fusionem universam), and, eventually, for equating Divinity with "fire, aether, water, earth, air, the sun, the moon, the stars and the whole universe" (universitatemque rerum) ${ }^{28}$ We can see clearly that Velleius' accusations are much more severe than those of Seneca or Plutarch. Velleius suggests that the Stoics do violence to traditional theology, and, when doing so, they put forward interpretations that are impious and irreligious. ${ }^{29}$ With the situation being as it is, the Stoics are not so much ludicrous (as Seneca or Plutarch would have it), but they are first and foremost blasphemous.

In what follows, I would like to show that all these grave charges levelled against Stoic hermeneutics result from their rather one-dimensional and reductionist view. All these accusations lose much of their sting when the Stoics' exegetical efforts are placed in a broader context of their original physics. Consequently, I shall examine the theological, allegorical and existential dimensions of Stoic etymologizing so as to show that the Stoics' pantheistic account of Divinity makes it actually quite natural for the philosophers to etymologize in search of God.

\section{The theological dimension of Stoic etymologizing}

For the Stoics, etymology is an encounter with God through language. Although the philosophers were often accused of blasphemy and iconoclasm, they did not want to annihilate the mythical symbols preserved in the language of traditional religious beliefs. The Stoics treated various names and epithets of the gods and goddesses as clues leading to what they regarded as a genuinely sacred reality. When assessing Stoic etymologizing, one must always bear in mind this strictly theological dimension of Stoic hermeneutics. As in the early Stoa

${ }^{26}$ Cic., De nat. d. I, 36 (= SVF I, 167).

27 Cic., De nat. d. I, 37 (= SVF I, 530).

${ }^{28}$ Cic., De nat. d. I, 39 (= SVF II, 1077).

${ }^{29}$ Goulet is clearly right in stressing that for Velleius the major flaw with Stoic theology lies in the fact that it is bound to "attribuer la divinité à des êtres inanimés dénués de sensation", GOULET, o.c. (n. 1), p. 111. 
etymological interpretation was assumed to provide access to authentic religiousness, it was through their etymologizing that the Stoics actually sought to make conventional mythology and religion truly relevant and meaningful. This can be clearly seen, if Stoic etymologizing is read through Cleanthes' Hymn to Zeus. The hymn opens with the following invocation:

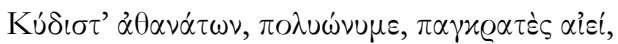

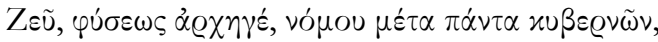

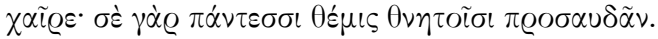

Most honoured of the immortals, Possessor of many names, Ever Almighty, Zeus, Chief of nature, who steers with Your law all things, hail to You. For to address You is right for the mortals, all of them. ${ }^{30}$

These epithets contain the quintessence of Stoic theology: God is an omnipotent Ruler of nature who is worshipped by men as having many names. Already in this invocation Cleanthes suggests that the task of knowing God is far too complex to be handled with a single and, thereby, reductionist account of

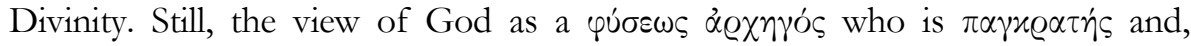

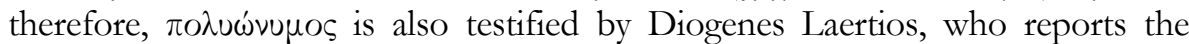
Stoics to have characterized God as "the Creator of the whole universe and, as it were, the Father of all, both in general and in particular, that part of Him which permeates everything, and which is called by many names in accordance with His

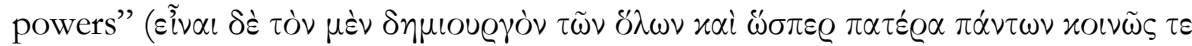

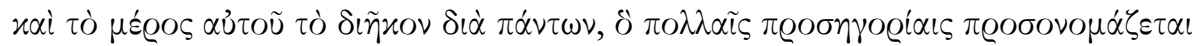

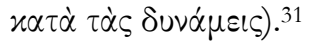

Read against the background of Cleanthes' hymn, this testimony suggests that various names of the gods and goddesses are but exterior manifestations of one and the same Deity: God is the omnipresent power that flows through everything and for that reason "He" is named by many appellations in correspondence with the particular expressions of "His" might. The Stoics' fundamental idea that God is the creative force of the universe that penetrates the world under various names and epithets is also testified by Aetius who relates that the Stoics identified God with "artful fire" that "systematically moves on to the creation of the

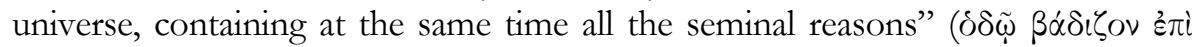

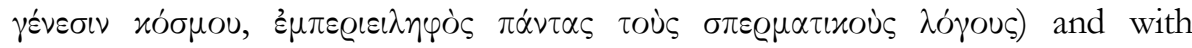
"breath" that "permeates the whole of the universe, assuming various names in accordance with the changes of matter through which it advances" ( $\mu \dot{\varepsilon} \nu \delta \tilde{\eta} \varkappa o v \delta \imath$ '

30 SVF I, 537 (lines 1-3). In the present paper, I avail myself of the translation that is to be found in P.A. MeIjER, Stoic Theology. Proofs for the Existence of the Cosmic God and of the Traditional Gods. Including a Commentary of Cleanthes' Hymn on Zeus, Delft, 2007, p. 209-228.

${ }^{31}$ Diog. Laert., VII, 147. 


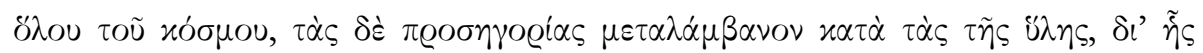

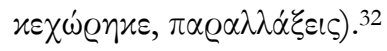

Naturally, the concepts of "artful fire" and "breath" signify here one and the same divine power: the fiery Pneuma is the ultimate creative force that produces all things of the world in accordance with its spermatic reasons. While this vital force is the Stoics' God, whom the philosophers elsewhere also characterize as

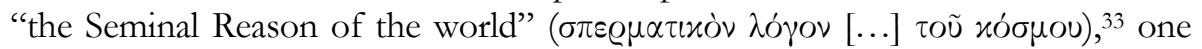
should note here how the Stoics combine vitalism with organicism: the ensouled universe is governed by a vital force whose various rationes seminales make the cosmos into an organic whole. Small wonder, then, that from the Stoics' perspective, all reality can be derived from such a God. Furthermore, this pantheism is also supported by radical hylozoism, since matter cannot be here separated from life: the whole of the world is for the Stoics alive, precisely because all matter is diffused, governed and animated by the fiery Pneuma.

One would be gravely mistaken though, if one assumed that the Stoics' pantheistic, vitalistic, organicistic and hylozoistic account of reality made the philosophers embrace some sort of monotheism. Stoic pantheism does not exclude polytheism. As a matter of fact, the Stoics' theology presupposes the existence of the whole Pantheon of various deities. In this respect, Plutarch relates that the Stoics regarded "none" (oủ $\varepsilon \dot{v} \alpha)$ of the gods as "imperishable or

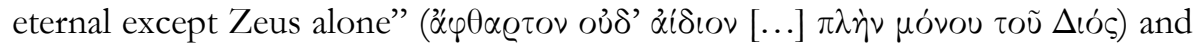

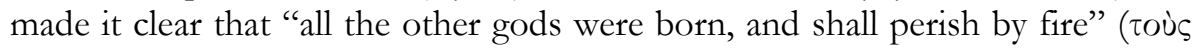

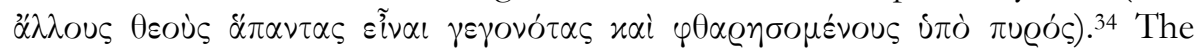
testimony shows that the Stoics did accept the existence of the traditional gods and goddesses. However, the philosophers reinterpreted the conventional polytheism in a very original way, since they assumed that there is one God that is immortal and indestructible, whereas all other deities are merely His contingent manifestations. That is why the Stoics could maintain that the conventional gods and goddesses (that are in fact only expressions of one and the same Divinity) have been born and will die in the cyclical conflagration that consumes the cosmos. ${ }^{35}$

32 SVF II, 1027. Diogenes Laertios (VII, $156=$ SVF I, 171) reports also the Stoics to have identified their "artful fire" ( $\pi \tilde{u} \varrho \tau \varepsilon \chi \nu \iota x o ́ v)$ and their "fiery and craftsmanlike Pneuma" ( $\pi \nu \varepsilon \tilde{u} \mu \alpha$

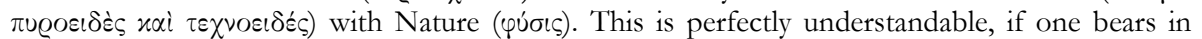
mind that in accord with their pantheism the Stoics always identify God with Nature. Cicero too attributes this idea to Zeno who is to have defined Nature precisely in this manner: Zeno igitur naturam ita definit ut eam dicat ignem esse artificiosum ad gignendum progredientem via (De nat. d. II, $57=$ SVF I, 171).

33 SVFI, 102.

34 SVF I, 536.

35 Already Wehrli has aptly observed (ad loc.) that "Zeus als der alles durchdringende Geist ist für den Stoiker allein unsterblich, alle anderen Götter erhalten ihre Namen nur durch die Materie, welche der göttliche Stoff durchläuft, und sind damit dem Wechsel und zeitweisen Untergang unterworfen”, F. WEHRLI, Zur Geschichte der allegorischen Deutung Homers im Altertum, Borna-Leipzig, 
In this context, one should therefore put it in no uncertain terms that the imperishable and eternal Zeus that Plutarch mentions is obviously not the actual ruler of Olympus. As already explained, God, according to Stoic theology, is the vital principle that penetrates and governs the whole of reality. Consequently, God is for the Stoics a dynamic being and fluctuating power, whose distinct names change as the God changes Himself. It is for this reason that the philosophers use interchangeably all such concepts as God, Zeus, Logos, Pneuma, Nature, Intellect, Fate, Providence and so on. From the perspective of Stoic pantheistic physics, all these notions refer to one and the same ultimate reality. Let us quote some relevant testimonies. We know that from Zeno onwards the

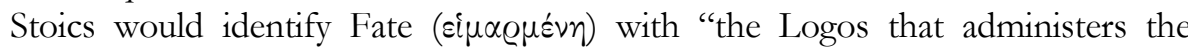

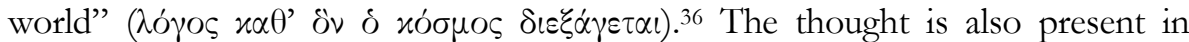
Cleanthes, who in his hymn specifies that Zeus "directs the common Logos"

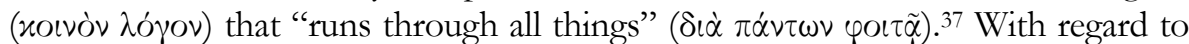
the third of the great founding fathers of the Stoa, Stobaeus relates that while

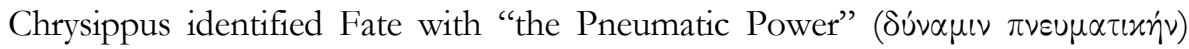
that arranges everything systematically, the philosopher also equated Fate with

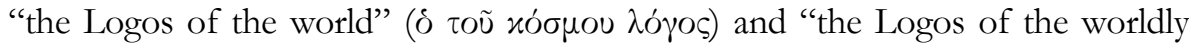

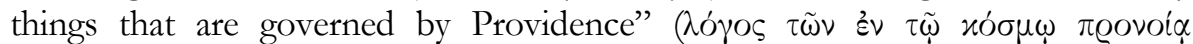

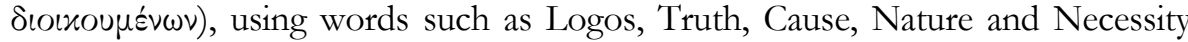
interchangeably. ${ }^{38}$ Finally, the early Stoics' pantheistic assumption about the fundamental interchangeability of all divine appellations is also confirmed by Diogenes Laertios, who reports the philosophers to have identified "God" ( $\theta \varepsilon o ̀ v)$,

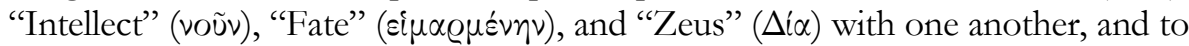

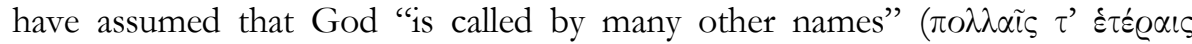

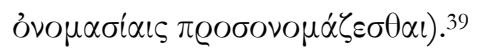

The Stoics' pantheism makes it, then, natural for the philosophers to assume that all individual deities can best be apprehended if they are taken as forming a cosmic unity. Conversely, this unity can be apprehended due to all the individual deities' harmonious interrelationships. God (whether He be called Logos, Fate, Intellect, Pneuma or Zeus) is a whole that defines and determines all individual aspects of Nature's divinity. In other words, the Stoics' pantheism results in the philosophers' conviction that it is impossible to know the whole of creation at once: one must rather begin with the various individual parts that derive their meaning from the organic whole. Thus, having known the individual deities, one

1928, p. 58. The same point has also been made by Colish: "The Stoics' particular aim in their allegoresis was to adjust their conception of a unitary deity and a monist physics to a polytheistic religion. They do this by interpreting the gods and apotheosized heroes as manifestations of the one central God", Colish, o.c. (n. 1), p. 34.

36 SVFI, 175.

37 SVF I, 537 (lines 12-13).

38 SVF II, 913.

${ }^{39}$ Diog. Laert., VII, 135-136. 
will become acquainted with the higher divinity of the cosmos, for just as one grasps the meaning of a whole sentence by identifying the meanings of individual words, so does one grasp God through various individual gods. This interconnectedness of the whole and its parts is pivotal to Stoic theology: God has stamped His Divinity upon every individual deity, and etymology is precisely what makes it possible to grasp this omnipresent divinity of the world through studying the names of the individual gods and goddesses. Inasmuch as etymology serves here the purpose of identifying the ontological unity of all deities, it becomes for the Stoics the very key to the sacred reality: etymologizing the particular names and epithets of the conventional gods (i.e., various revelations of God) helps to light up the phenomenon of the divinity of the universe from various sides.

We can now see clearly that the purpose of the early Stoics' etymologizing is profoundly religious: through their etymologizing the philosophers seek to find God, whom they identify with the world and whom they, therefore, assume to manifest differently and to adopt many diverse names in accordance with His distinct powers. The clearest exposition of this thoroughly religious etymologizing comes from Diogenes Laertios who reports the Stoics to have assumed God

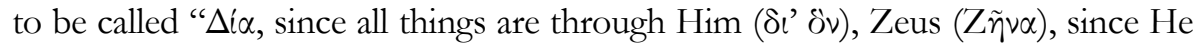
is the cause of, or permeates life $(\zeta \tilde{\eta} \nu)$, Athena as His governing faculty extends to the aether; Hera as it extends to the air, Hephaestus as it extends to the artful fire

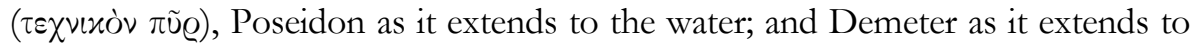
the earth". ${ }^{40}$ While Diogenes Laertios puts it in no uncertain terms that the Stoics "in the similar way attributed [to God] various other names, positing a certain

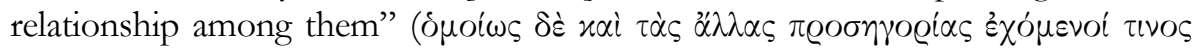

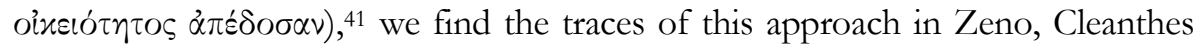
and Chrysippus: for all of the early Stoics various names and epithets denote, in fact, one and the same Deity that only makes itself known differently.

Thus, Chrysippus is reported to have explained Zeus' name from the fact that the god "gives life to everything" ( $\pi \tilde{\alpha} \sigma \iota \delta \varepsilon \delta \omega x \varepsilon \dot{v} \alpha \iota$ iò $\zeta \tilde{\eta} \nu)$, whereas the accusative form $\Delta i \alpha$ was derived by the philosopher from the fact the god "is the cause of

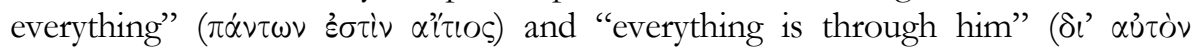
$\pi \alpha \dot{\alpha} \tau \tau) .{ }^{42}$ While this etymology goes back to Plato, ${ }^{43}$ Cornutus' account testifies that it was embraced by some of the later Stoics too. When drawing a parallel between the soul that governs men and the soul that the world has, Cornutus

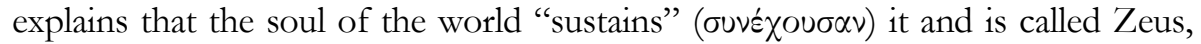
because it is "living" ( $(\tilde{\omega} \sigma \alpha)$ and because it "is the cause of life for all living

\footnotetext{
40 Diog. Laert., VII, 147.

${ }^{41}$ Diog. Laert., VII, 147.

42 SVF II, 1062. An analogous explanation of Zeus' name appears in SVF II, 1076.

${ }^{43}$ In the Cratylus (396a7-b2), Socrates identifies Zeus' with the "cause of life" ( $\alpha^{\prime}$ í $\zeta \tilde{\eta} \nu)$ and explains the all "life is through him" ( $\delta \iota$ ' $\delta \nu \zeta \tilde{\eta} \nu)$.
} 


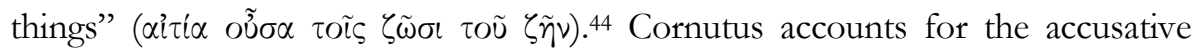
form in a manner that also clearly echoes Chrysippus. According to Cornutus, Zeus is called $\Delta i \alpha$, for it is "because of him that everything comes into being and

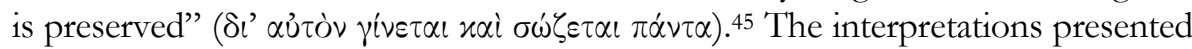
by Chrysippus and Cornutus clearly build on the assumption that Zeus is just one of the many manifestations of God. In this particular case, the god is an expression of the Life-Giving-Cause: Zeus pervades all life and is, therefore, the ultimate source of it. While the name "Zeus" reflects the creative and lifebringing aspect of Divinity, we can see that etymologizing the god's name makes it possible for the Stoics to justify their vitalism: Zeus stands simply for the vital principle of the ensouled universe.

Consider now Cleanthes. We have seen that the philosopher interpreted the sun as both Apollo ${ }^{46}$ and Dionysus. ${ }^{47}$ Cleanthes' identification of the sun with the two gods at the same time does not have to be dismissed as inconsistent and contradictory. From the perspective of Stoic pantheism, one interpretation of God does not automatically make another one invalid. Rather than being selfrefuting, the two interpretations focus on different aspects of God's activity: on the one hand the sun "rises at different times at different places" and, on the other, it "completes the circle of the heavens, making, thereby, the day and the night". In yet another etymological explanation, Cleanthes derived Apollo's epithet Loxias from the fact that the sun moves along a spiral trajectory and the spirals are "oblique" ( $\left.\lambda_{\circ} \xi \alpha i\right) .48$ We see clearly here that Cleanthes' interpretations shed light on the various aspects of the divinity of the sun: God is the source of everything and that is why the imprints of His activity can be observed from diverse perspectives. The Stoics' pantheism results, thus, in a very original use of etymology: rather than being the study of words' origins and shapes, etymology becomes here the study of how God develops and reveals Himself in the various phenomena of our world.

It is also the founder of Stoicism that seems to have treated etymology as the study of God's various manifestations. Thus, Zeno equated Hesiod's Xáoৎ with water, basing his interpretation on the verb to "pour" or "be flowing" ( $\chi \varepsilon \varepsilon \varepsilon \sigma \alpha \iota) .49$ This interpretation is also confirmed by a testimony, which additionally presents

\footnotetext{
${ }^{44}$ Corn., 3, 3-6.

45 Corn., 3, 8-9.

46 See supra, note 2. In the Cratylus (404e 1 - 406a 3), Socrates perceives the alternative etymologies of Apollo as complementary rather than contradictory. Cf. also supra, note 11.

${ }^{47}$ See supra, note 3 .

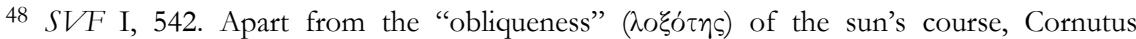
suggests $(67,14-16)$ that the epithet may be due to the fact that the god's oracles are "ambiguous" ( $\lambda \circ \xi_{\circ}$ i).

49 SVF I, 103. As already observed (see supra, note 21), a highly comparable exegesis appears

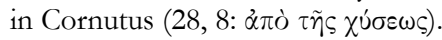


an excerpt from the philosopher's cosmogony: while the condensation of water generates mud which then solidifies into earth, the third factor involved in the generative process is Eros (i.e., fire). ${ }^{50}$ Hence, Zeno's cosmogony seems to build on three generative forces: Chaos, Earth and Eros. Although the existence of such an account is corroborated by Plato, ${ }^{51}$ there are some problems concerning this interpretation of Hesiod, since it appears to presuppose either an equation of Earth with Tartarus, or an omission of Air. ${ }^{52}$ The problems disappear, though, when we recall that the Stoics posited the existence of a certain "affinity"

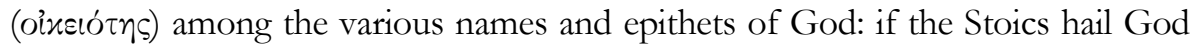

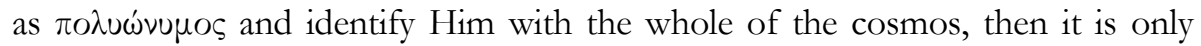
natural for the philosophers to perceive the particular names and epithets of the gods and goddesses as appellations of one and the same Deity.

Let us recall here that in Stoicism God is not a person. God is the creative power of the universe that is identical with Nature, whereas all the conventional anthropomorphic gods and goddesses are merely manifestations of this generative force. If God is not a person, but rather an aggregate of Nature's various expressions, then it is understandable why the Stoics assume that one can reach God through etymological interpretations: it is in this way that one can decipher the imprints of Divinity on all Being. The quality of "having many titles" which Cleanthes in his hymn attributed to Zeus is characteristic of Divinity as such: God is called Logos, Pneuma, Intellect, etc., for as "He" transforms "Himself", so do "His" appellations change accordingly. In this context, Aetius reports that

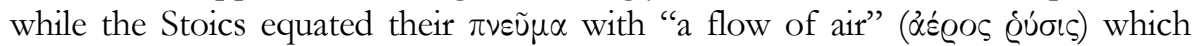

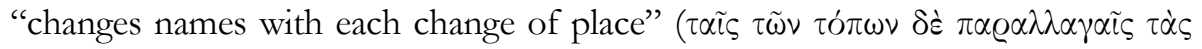
$\varepsilon \pi \omega \nu \cup \mu i \alpha \varsigma \pi \alpha \varrho \alpha \lambda \lambda \dot{\alpha} \tau \tau O \nu \sigma \alpha \nu)$, they would illustrate the tenet with such etymologies

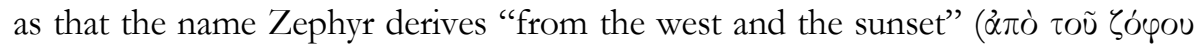

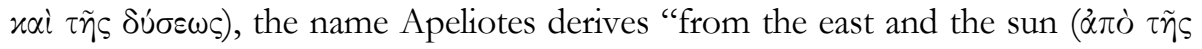

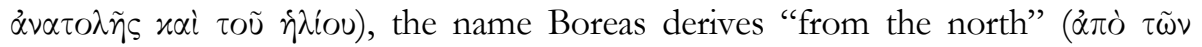

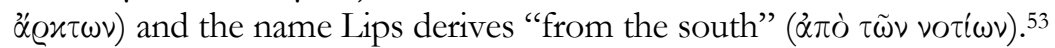

Whilst the last two explanations are admittedly not particularly obvious, overall the testimony clearly shows the Stoics to have taken their God-Pneuma to be the source, cause and end of all things. The philosophers maintained that everything participates in God, for everything that is, has been and ever will be, can be found (in more or less embryonic form) in the Pneuma. That is why in Stoic pantheistic theology God has many appellations and proportionally many manifestations: when God is referred to as Pneuma, it has to be remembered that He embraces all such expressions of the flow of air as Zephyr, Apeliotes, Boreas

\footnotetext{
50 SVF I, 104.

51 Pl., Symp., 178 b 8-9.

52 Cf. AlgRA, l.c. (n. 21), p. 567.

53 SVF II, 697.
} 
and Lips. Similarly, this God-Pneuma comprises also the four elements. ${ }^{54}$ Diogenes Laertios makes it clear that although the Stoics distinguished between the four elements (fire/aether, air, water and earth), they were inclined to perceive them all as revelations of one and the same force governing the world. ${ }^{5}$ Relatedly, Alexander of Aphrodisias specifies that the Stoics adopted the idea of the four elements, but that they let fire and air coalesce into the Pneuma. ${ }^{56}$ Lastly, Cicero, when referring to the Stoic doctrine, stresses the "similarity" (similitudo) and the "the highest union" (summa coniunctio) of air and aether. ${ }^{57}$

One could obviously cite much more evidence for the early Stoics' proclivity to regard the various aspects of the universe as expressions of one and the same Deity, but it seems enough to note here that all Stoic reductions of the traditional gods and goddesses to physical phenomena can be subsumed under the following generalization: whether we are dealing with mythological characters (Zeus, Hera, Poseidon, Hephaestus, Athena, Demeter, Persephone, Chaos, Cyclopes, etc.) or philosophical concepts (Logos, Pneuma, Intellect, Nature, Fate, Necessity, Cause, Truth, etc.), God is for the Stoics a reality that encompasses all these entities. That is why, as we have seen, one and the same physical phenomenon could be equated with two different gods (e.g. the sun was identified with both Dionysus and Apollo, whereas aether was identified with both Zeus and Athena). We may, therefore, conclude that while in Stoic pantheistic theology God changes permanently and adopts various names accordingly, the various alternative etymologies are for the Stoics complementary rather than contradictory. The Stoics understand their God as the omnipresent and omnipotent cosmic force that animates and steers the ensouled world. If from a philosophical perspective the force is described in such terms as God, Logos, or Pneuma, then from an ordinary view the force is labelled as Zeus, Poseidon, or Hephaestus. It goes without saying though that for the Stoics both terminologies are actually two sides of the same coin: philosophical theories and folk conceptions point to the imprints of one and the same Divinity, whose manifestations can be captured by both

\footnotetext{
54 Zeno is reported to have interpreted the four major Olympians in such a manner that Juno (Hera) became air, Jove (Zeus) became the heavens (i.e. aether), Neptune (Poseidon) became the sea (i.e. water) and Vulcan (Hephaestus) became fire (SVF I, 169), whereas Chrysippus was supposed to have equated Jove (Zeus) with aether (i.e., fire) and Juno (Hera) with the lower (layer of) air (SVF II, 1066). Whilst in Chrysippus Hera is aer that is subiectus igni (i.e., Iovi), this identification of Hera with air is also testified by Cornutus, 3, 16.

55 Diog. Laert., VII, 136-137 and 147.

56 SVF II, 310, 442, 786.

${ }^{57}$ De nat. d. II, 66. This coalescence of fire and air is also reflected in an interpretation put forward by Heraclitus the Allegorist, cf. Heraclitus, Homeric Problems, 15, 3 (ed. D.A. RusseLL, D. Konstan, Atlanta, 2005). This generally non-Stoic author deciphers Hera's epithet "white-

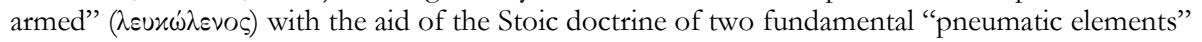
$(\tau \tilde{\omega} \nu \pi \nu \varepsilon \cup \mu \alpha \tau \iota x \tilde{\omega} \nu \sigma \tau o \iota \chi \varepsilon i \omega \nu)$. Hence, the epithet is read as symbolizing an interaction of aether (Zeus), i.e., the "fiery substance" ( $\pi \cup \varrho \omega \dot{\delta} \eta \varsigma$ oủ $\sigma i \alpha)$ with air (Hera), i.e., the "softer element"

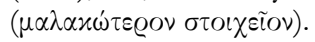


philosophy and mythology. In order to make the two different descriptions of one and the same reality meet, the Stoics avail themselves of allegoresis.

\section{The allegorical dimension of Stoic etymologizing}

For quite a few decades now, there has been an ongoing debate as to whether (and if so, to what extent) Stoic hermeneutics can be characterized as allegoresis. While the preponderance of scholars do classify Stoic exegetical efforts as allegorical, ${ }^{58}$ the authors who in one way or another object to the idea of Stoic allegoresis ${ }^{59}$ base their reservations on a very sharp distinction between allegory and etymology. Although one should naturally be very careful so as not to hastily identify and thereby confuse the two, overemphasizing the difference between allegory and etymology can prove equally misguided, since both these exegetical procedures frequently presuppose and complement each other. ${ }^{60}$ This coalescence of allegory and etymology can indeed be observed in some of the exegeses put forward by the Stoics. Let us look at several examples.

Zeno's etymological interpretation of Hesiod's Chaos seems to be a rather clear-cut example of allegorization. ${ }^{61}$ As we have seen, it came to play a crucial

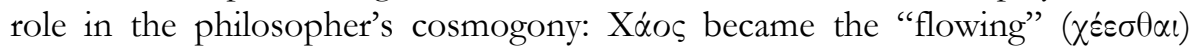
water, whose condensation generated mud, which then congealed into the Earth. The allegorical nature of Zeno's interpretation is testified by yet another source. The testimony has Zeno claim that the Earth originated from some

\footnotetext{
58 See for example: J. TATE, “Cornutus and the Poets”, CQ 23 (1929), p. 41-45; P. DeLACY, "Stoic Views of Poetry", AJPh 69 (1948), p. 241-271; BufFIĖRE, o.c. (n. 1), p. 148-154; J. PÉPIN, Mythe et allégorie: Les origines grecques et les contestations judéo-chrétiennes, Paris, 1976, p. 125-131; COLISH, o.c. (n. 1), p. 34; R. LAMBERTON, Homer the Theologian: Neoplatonist Allegorical Reading and the Growth of the Epic Tradition, Berkeley, 1986, p. 25-26; WHITMAN, o.c. (n. 1), p. 31-47; BLÖNNIGEN, o.c. (n. 1), p. 27-31; D. DAwson, Allegorical Readers and Cultural Revision in Ancient Alexandria, Berkeley, 1992, p. 32; Brisson, o.c. (n. 1), p. 61-69; G.R. Boys-STOnES, "The Stoics' Two Types of Allegory", in id. (ed.), Metaphor, Allegory and the Classical Tradition: Ancient Thought and Modern Revisions, Oxford, 2003, p. 189-216 and STRUCK, o.c. (n. 1), p. 111-113.

59 Most notably P. STEINMETZ, "Allegorische Deutung und allegorische Dichtung in der alten Stoa", RhM, 129 (1986), p. 18-30; and A.A. Long, Stoic Studies, New York, 1996, p. 58-84 (chapter III: "Stoic Readings of Homer").

60 This, rather uncontroversial, opinion has been justly emphasized by Goulet: "La distinction entre interprétation étymologique des noms des dieux et commentaire allégorique des textes d'Homère et d'Hésiode ne doit pas nous conduire à penser que l'étymologie ne pouvait pas être employée dans un contexte allégorique, tout au contraire. L'étymologie est un élément privilégié de la méthode allégorique, dans la mesure où elle suggère un symbolisme qui ne dépend pas entièrement de l'arbitraire du lecteur", GoulET, o.c. (n. 1), p. 113-114. Although the context is quite different, Dixsaut reaches nevertheless a highly comparable conclusion too: "L'étymologie devient alors non seulement le moyen privilégié de l'éxégèse, elle est en elle-même exégèse", Dixsaut, o.c. (n. 11), p. 162. Lastly, Sedley is clearly also right when he stresses that ancient etymology is best understood when it is viewed as "more closely analogous to modern literary criticism than to modern etymology", SEDLEY, o.c. (n. 11), p. 37.
}

61 Cf. supra, notes 21 and 49. 


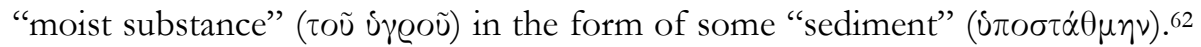
Evidently, the "moist substance" is water, which the philosopher identified allegorically with X'́os. Equally allegorical in nature are also Zeno's equations of the Cyclopes with "circular motions", 63 and of the Titans with "the elements

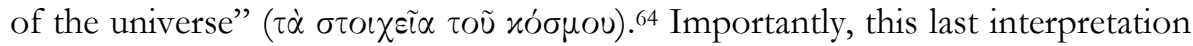
has been taken up by Chrysippus, who is reported to have offered a highly comparable account of the Titans. ${ }^{65}$ While already this testimony shows also "the second founder of the Stoa" to have combined etymology with allegory, ${ }^{66}$ another example of such an etymological allegorization could be Chrysippus'

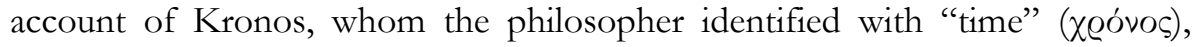
and, basing this interpretation on etymology, accounted for the god's "swallowing" ( $x \alpha \tau \alpha \pi_{i}(v \varepsilon \iota v)$ of Rhea's children in terms of all things' coming into being in

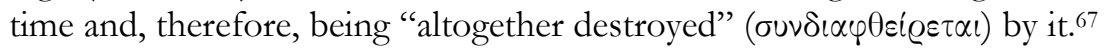

\footnotetext{
62 SVF I, 105.

${ }^{63}$ Cf. supra, note 22.

64 SVF I, 100.
}

65 SVF II, 1086. Cf. MeIJER, l.c. (n. 30), p. 103 (n. 549). If we compare the interpretation attributed to Zeno (SVF I, 100) with the one ascribed to Chrysippus (SVF II, 1086), then the

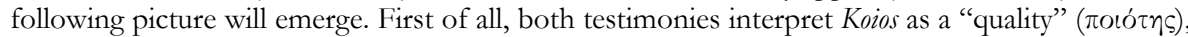
although only the former justifies this reading etymologically, hypothesizing about the Eolian change of $\pi$ into $\%$. Secondly, the testimonies complement each other in their interpretation of Kreios: whilst the former identifies the Titan with "the commanding and controlling principle" ( $\tau$ ò

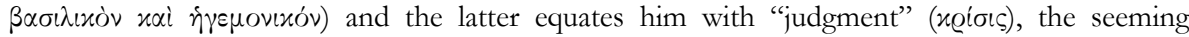
difference is easy to reconcile if one bears in mind that the governing part of our soul is responsible for making judgments. Thirdly, both testimonies connect the name Hyperion with

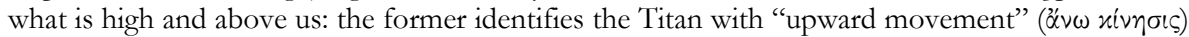

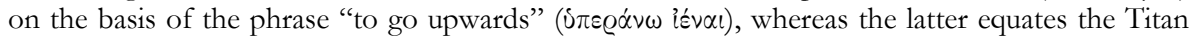

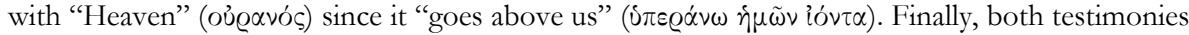
associate the name Iapetos with some motion: the former derives the name from the fact that all light things, when set free, naturally "fall upwards" ( $\pi i \pi \tau \varepsilon \iota \nu ~ \ddot{\alpha} \nu \omega)$, while the latter identifies the

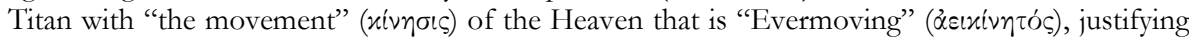
this reading etymologically by reference to the verbs " $\varepsilon \sigma \theta \alpha \iota$ and $\pi \varepsilon \varepsilon_{\tau} \varepsilon \sigma \alpha \alpha$. Admittedly, the biggest difference between the two testimonies consists in that Chrysippus is also reported to have

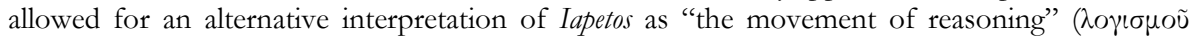

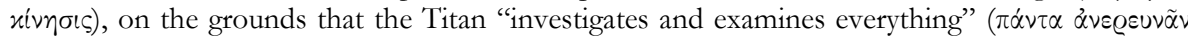

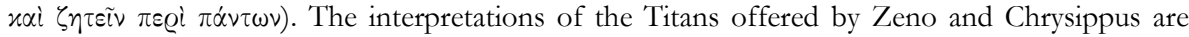
alluded to in Cornutus (30, 8-18).

${ }^{66}$ Chrysippus' allegorical interpretation of the votive image of Hera fellating Zeus would clearly be the most obvious example of the philosopher's allegoresis (SVF II, 1071-1074). However, the exegesis does not immediately involve etymology and is, therefore, outside the scope of the present paper.

67 SVF II, 1087. While parallel accounts are also given by Cornutus $(6,20-7,5)$ and Cicero (De nat. d. II, 64), the allegorical nature of this interpretation is most clearly evidenced by Heraclitus the Allegorist. Heraclitus interprets Homer's narrative about Hera's oath (Il. XV, 3637) and the world's partitioning (Il. XV, 190-193) in such a manner that "the whole story

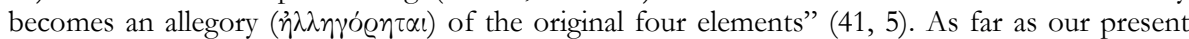
considerations are concerned, the Allegorist's most important point is that Kronos is identified

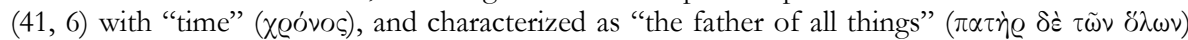

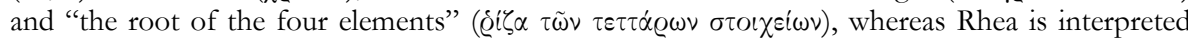


As for Cleanthes, we have already cited the philosopher's identification of Persephone with "the productive and destructive Pneuma". 68 This allegorization seems to build on Persephone's being both the goddess of fertility (i.e. a symbol of birth) and the queen of the underworld (i.e., a symbol of death). Yet another example is the philosopher's reading of Atlas. Cleanthes is reported to have

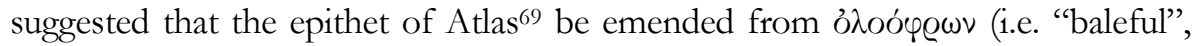

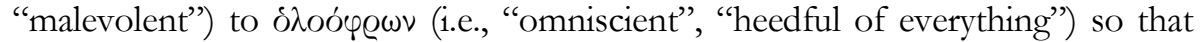
Atlas could stand for "indefatigable and untiring providence" ( $\alpha x \alpha \dot{\alpha} \mu \tau$ cov $x \alpha i$

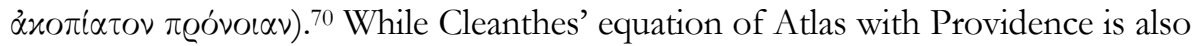
a good example of allegorization, the Stoic nature of this interpretation is confirmed by Cornutus. ${ }^{71}$

All the aforementioned cases of Stoic allegorization build on the assumption that the Pantheon of the Greek gods is actually a self-externalization of one pantheistic God (Pneuma, Logos, Nature etc.). They reveal that the Stoics assumed the very idea of God to require recourse to allegory. Suffice it to cite here Cleanthes' famous assertion that poetry "in the highest degree possible approaches the truth about contemplating the gods" ( $\dot{\omega} \varsigma \mu \alpha \lambda \iota \sigma \tau \alpha \pi \varrho 0 \sigma \iota \nu \varepsilon i \sigma \theta \alpha \iota$

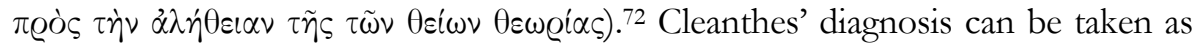
representative of the Stoic attitude to poetry in general: for all early Stoics, God comes most fully to expression in poetry. That is also why the philosophers interpret the particular excerpts from poems as clues pointing to the various revelations of God. When doing so, the Stoics translate the conventional mythology of the poets into terms acceptable from the point of view of their pantheistic theology, so that the gods of Homer and Hesiod become symbols of the various aspects of the ultimate reality (i.e., the all-embracing God of the philosophers).

At this point, it needs to be stressed though that while the Stoics do combine etymology with allegory, there is no apologetic dimension in their exegeses: the Stoics never allegorize with a view to defending the poet(s). This is due to their conviction that the soul of the poem is not the author's intentions. The frequently discordant writings of the poets camouflage the profound coherence of the Logos that manifests itself independently of anybody's design. The Stoics

$(41,7)$ as "the mother" ( $\mu$ ín $\varrho)$ of the four elements on the grounds of the fact that the universe

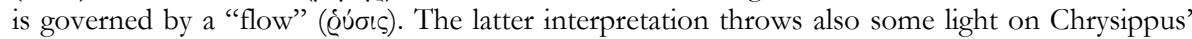
interpretation of Rhea. The philosopher is reported (SVF II, 1084) to have explained that the goddess stands for the Earth, since all "waters flow from her" ( $\left.\alpha \pi^{\prime} \alpha \dot{\jmath} \tau \tilde{\eta} \varsigma \oint \varrho \varepsilon \tilde{\imath} \tau \dot{\alpha} \cup \delta \alpha \tau \alpha\right)$. Cf. also Cratylus (402a $9-\mathrm{b} 4)$ and Cornutus $(5,10)$.

${ }^{68}$ Cf. supra, note 20.

${ }^{69}$ Hom., Od. I, 52.

70 SVF I, 549. Struck rightly stresses that Cleanthes' textual emendation has been made "on allegorical grounds", STRUCK, o.c. (n. 1), p. 143.

${ }^{71}$ Corn., 48, 16: $\pi \varepsilon \varrho i ~ \tau \tilde{\omega \nu ~ o ̈ \lambda \omega \nu ~ \varphi \varrho o v \tau i \zeta \varepsilon i \nu . ~}$

72 SVF I, 486. 
assume that there are limits to how a poet (even one as great as Homer or Hesiod) can transmit the overwhelming reality he poetizes about. And that is precisely why the very idea of God requires recourse to allegory. That is also why the philosophers do interpret poetry allegorically even though they never suggest that the meaning of a verse exhausts itself in what the author wished to convey. We may, therefore, say that the Stoics want to understand the poem, not the poet. While this understanding of poetry consists in translating it into Stoic pantheistic philosophy, it very often entails some allegorization.

In the context of Stoic theology, one should, therefore, emphasize that the philosophers' belief that God is most clearly displayed in poetry and mythology has several important ramifications. First of all, the Stoics do not interpret poetry and mythology as ends in themselves, but rather as means to grasp the higher ontological unity of deities. The philosophers abstract from the intentions of the author: the names and epithets of the gods and goddesses are symbols of a deeper reality, but these expressions of God are never expressions of an individual poet. The intentions of Homer, Hesiod or any other author are completely irrelevant, since their subjectivity remains totally impenetrable. If, however, mythology and poetry are regarded as expressions of God, then these expressions (merely transmitted by the poet) may be taken as objective. Thus, the principal raison d'etre of poetry is that it provides access to God and not some aesthetic thrill. Furthermore, the Stoic idea of extracting Divinity from poetry and mythology presupposes that God can be understood objectively through and owing to His manifestations in language. ${ }^{73}$

Language is, therefore, seen as a set of expressions of God and not of the poets (i.e., their thoughts, feelings, values etc.). Hence, it is also clear why the Stoics resort to etymology: all Being (God included) is mediated in language and for that reason it is accessible only through language. With that, the Stoics introduce into our culture the view that language is the reservoir of a society's cultural experiences and that investigating it becomes tantamount to investigating the society's conception of the world. In other words, the Stoics saw that while language preserves a particular vision of reality, man is hardly aware of the fact that such facets of his existence as, say, his worshipping, are encoded in language. Consequently, for the Stoics it is not only the ultimate reality of God-Pneuma

73 While the Stoics' practice of etymology presupposes a one-to-one correspondence between language and external reality, I discuss the issue more fully in: M. DOMARADZKI, "Allegory, Symbol, or Metaphor? Chrysippus' Hermeneutics and the Problem of Ambiguity” [forthcoming]. Here, I would merely like to observe that Augustine's De dialectica (VI, 10-11) and Origen's Contra Celsum (I, 24) make it clear that the Stoics assumed words to mimic the world. As the philosophers posited the existence of a natural bond between names and their referents (resulting precisely from the fact that every word reproduces reality), they believed also the names of the gods to be motivated precisely in this way. Consequently, the Stoics were convinced that etymology makes it possible to account for the fact why Zeus is the symbol of $\zeta \tilde{\eta} \nu$, Hera is the

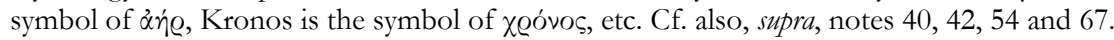


that is accessible through language: all reality and all being can only be grasped through words. If language is the most fundamental medium for the transmission of the divine, then it has to be stressed that reaching this hidden and sacred aspect of reality requires transcending the literal dimension of language. As we have seen, this transcending consists in allegorizing.

Where does that leave us, then, with regard to the accusations that were raised against the Stoics by such detractors as Velleius? Contrary to what these critics purport, the Stoics do not call for some sort of religious purge, as a consequence of which all the conventional deities become abolished and all the traditional forms of cult are declared useless. The Stoics do not opt for such a demystification of religion that results in its reduction to plain superstition. Rather, the philosophers believe that investigating the particular names of the gods and goddesses delivered by tradition is crucial, since all these names light up the divinity of the universe from various sides. If the particular appellations of diverse deities are but revelations of one pantheistic God, then discovering the hidden symbolic reality that underlies mythology is not tantamount to discarding religion. That is why it has been stressed at the outset that the Stoics reinterpret religion, not demolish it. Obviously, the philosophers sometimes undermine traditional religion, but when doing so, they seek to lay the foundations for a deeper and more authentic religiousness. With that, we come to one of the most original and astounding aspects of Stoic etymologizing: as studying the names of the gods is for the philosophers identical with discovering God, etymology becomes for them the tool for transforming our existence.

\section{The existential dimension of Stoic etymologizing}

Etymologizing receives in Stoicism an important ethical and existential dimension, as by making genuine religiousness possible, it changes, thereby, our lives. In his hymn to Zeus, Cleanthes passionately condemns "all those among the mortals

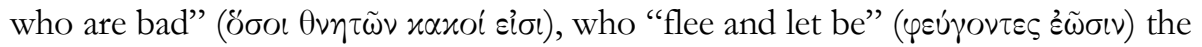
Logos, and "the wretched" ( $\delta \dot{\sigma} \sigma \circ \varrho \circ)$ who "neither look to the Universal Law of

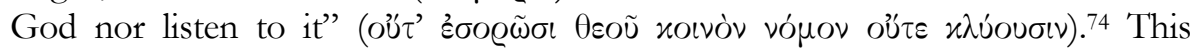
exhortation to seek the Universal Law of God shows that for the Stoics the study of etymology has primarily ethical values: it serves the purpose of knowing God and, as we shall shortly see, of enabling us to live in conformity with His will. This spiritual and existential dimension of Stoic etymologizing seems to be a debt that the philosophers have contracted with Heraclitus. 
It has been proved beyond any doubt that Cleanthes' hymn is profoundly indebted to Heraclitus of Ephesus (as is Stoic philosophy in general). ${ }^{75}$ As far as our considerations are concerned, the following three points made by Heraclitus are absolutely crucial for understanding the existential dimension of Stoic etymologizing. First of all, while Heraclitus pointed to "the judgment $(\gamma \nu \omega \dot{\mu} \mu \eta \nu)$, by which all things are steered through all", ${ }^{76}$ Cleanthes spoke of "the judgment $(\gamma \nu \omega \dot{\mu}\rangle s)$ by which Zeus steers all things with justice". ${ }^{77}$ Secondly, Heraclitus insisted on the existence of "One Divine Law" that nourishes all human laws, ${ }^{78}$ whereas Cleanthes, as we have just seen, censured those who fail to seek "the Universal Law of God". ${ }^{9}$ Finally, having recommended "listening to the Logos", ${ }^{80}$ Heraclitus asserted that God "does not and does consent to be called by the name of Zeus". ${ }^{81}$ Again, this motif was also embraced by Cleanthes who, as already mentioned, spoke of Zeus" directing "the common Logos" that "runs

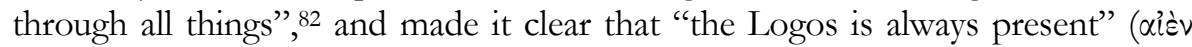

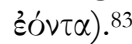

We see, then, that Cleanthes agrees with Heraclitus that there is an intelligent principle that steers the universe. While the principle is referred to as either the Logos or Zeus, it governs not only the whole world but also every individual man. Consequently, and this is the most important affinity between Heraclitus and Cleanthes, both thinkers draw significant moral consequences from the necessity to recognize and follow the common Logos/Nomos. ${ }^{84}$ Thus, whilst Heraclitus stresses the moral obligation to follow "the common Logos", 85 the ethical task of acknowledging and obeying the common Logos appears also in Cleanthes, who stresses that if people "obeyed" ( $\pi \varepsilon \imath \theta$ ó $\mu \varepsilon v o \iota)$ the Universal Law of

\footnotetext{
75 I have benefited greatly from a very useful and inspiring discussion of Heraclitus' impact on Cleanthes' hymn that is to be found in: LONG, o.c. (n. 59), p. 46-52. The whole second chapter of the book ("Heraclitus and Stoicism", p. 35-57) is also to be recommended as a very instructive treatment of Heraclitus' influence on the Stoics.

${ }^{76}$ D.K. 22 B 41.

77 SVF I, 537 (line 35). Cf. G.S. KIRK, J.E. Raven, M. Schofield, The Presocratic Philosophers. A Critical History with a Selection of Texts, Cambridge, 1983, p. 202. The translations of Heraclitus are generally Kirk's, but I felt free to slightly modify them at times.

${ }^{78}$ D.K. 22 B 114.

${ }^{79}$ Cf. supra, note 74 .

${ }^{80}$ D.K. 22 B 50.

${ }^{81}$ D.K. 22 B 32. The Znvòs that Heraclitus uses here seems to be echoed in several Stoic exegesis, cf. supra, notes 40 and 42 .

82 Cf. supra, note 37.

83 SVF I, 537 (line 21).

${ }^{84}$ LONG, o.c. (n. 59), p. 48-49. Obviously, the words logos and nomos are notoriously polysemous, but in Cleanthes' hymn they can be taken to overlap, see in this respect MEIJER, o.c. (n. 30) p. 228. This is part and parcel of the Stoics' using appellations such as God or Logos interchangeably.

85 D.K. 22 B 2.
} 


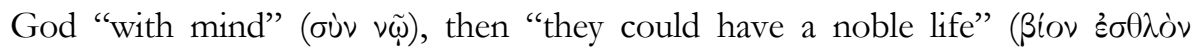

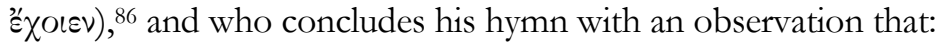

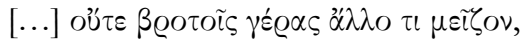

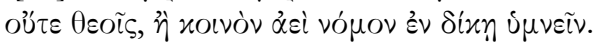

$[\ldots]$ there is no greater gift to offer both for mortals and gods than, in justice, of the universal law always to sing. ${ }^{87}$

The moral imperative to recognize and follow the Logos shows that Heraclitus and Cleanthes let ethics and ontology coalesce. This coalescence of ethics and ontology is most clearly visible in the Stoics' specification that the "objective"

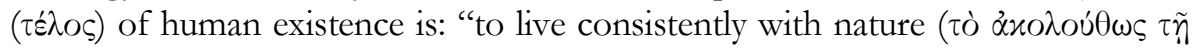

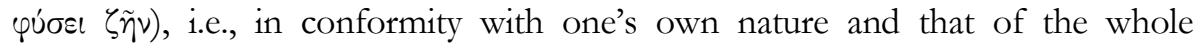
universe, doing nothing that is prohibited by the Common Law (ó vópos o xoเvós), which is identical which the All-Pervading and Right Logos (ó ỏ $\theta$ ò $\varsigma$

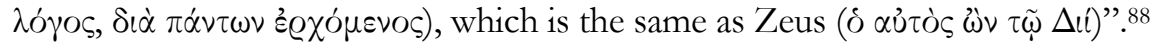

According to the Stoics, then, participation in the Logos is the most precious gift that God has bestowed upon men. It is at the same time a blessing and a calling. Men return the blessing and fulfill their calling by recognizing God's omnipresence in the surrounding universe. The recognition takes place in and through language: etymologizing the names and epithets of the particular gods and goddesses leads men to acknowledge the existence of one pantheistic God. Thus, etymology receives its religious justification in Stoicism: it becomes a tool for honouring God, since it makes men aware that diverse deities are but revelations of one ultimate Divinity. As we have seen, Stoic physics builds on the idea of divine and amorphous matter that is penetrated, animated and steered by the fiery Pneuma, While the term "Pneuma" is used here interchangeably with such terms as "God" or "Logos", the Stoics identify their Pneuma with the World Soul. The philosophers make it clear that "life and soul are nothing but

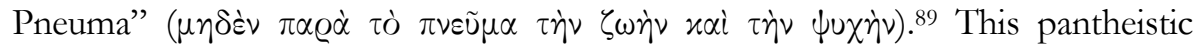
characterization of the Pneuma as the soul of the universe is significant, since it shows that the Pneuma is not only the world's pervading formative principle but also the most central point of our existence: just as our immersion in the Pneuma causes us to live in and through it, so does it cause us to obtain all our knowledge via the Pneuma.

The parallelism between macrocosm and microcosm that the Stoics draw has an important existential consequence. If, as has been noted above, Divinity can

\footnotetext{
86 SVF I, 537 (line 25).

87 SVF I, 537 (lines 38-39).

${ }^{88}$ Diog. Laert., VII, 88 (= SVF I, 162).

89 SVF II, 443. We know that from Zeno onwards, the Stoics identified the soul with the fiery Pneuma. Accordingly, in SVF I, 135 the soul is termed as $\pi v \varepsilon \tilde{u} \mu \alpha$ év $\theta \varepsilon \varrho \mu o v$, whereas in $S V F$

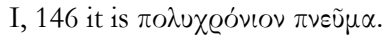


be made present to us through pious etymologizing, then we can now clarify that we grasp the divine Pneuma through etymology, since we all participate in the Pneuma and always remain a part of it. Thus, by studying the diverse manifestation of the Pneuma, we come to understand not only God, but also ourselves. It goes without saying, though, that such knowledge is not merely to be possessed but to be lived in. Hence, etymology becomes in Stoicism a tool for not only honouring God, but also for transforming one's life. Cleanthes' promise that living in accord with God's Universal Law will guarantee men noble lives must be placed in the context of the Stoics' idea of reforming the then religion.

The Stoic Balbus laments over the poor condition of conventional religion which, as he puts it, provides ludicrous and absurd details on the gods' "outward appearances" (formae), their "age, clothes and equipment" (aetates et vestitus ornatusque), their "descents, marriages, relationships" (genera [...] coniugia cognationes), their "agitated minds" (perturbatis animis), their "passions, sorrows, angers" (cupiditates aegritudines iracundias), their "wars and battles" (bellis proeliisque), and - in a word - on "everything that was projected [on them] in the likeness of human weakness" (omniaque traducta ad similitudinem inbecillitatis bumanae)..$^{90}$ While in this passage, Cicero has Balbus diagnose that religion has degenerated into crude and naive anthropomorphism, we find the same assessment of religion's condition in Chrysippus, who deplores that "the gods are spoken and written of childishly $(\pi \alpha \iota \delta \varrho \iota \omega \delta \tilde{\omega} \varsigma)$ and portrayed anthropo-

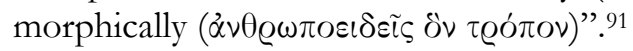

These diagnoses show that the Stoics were deeply dissatisfied with conventional mythology and religion, which in their eyes amounted to shallow superstition and spiritless ritualism. Yet, the deplorable state of the existing system of beliefs did not prompt the philosophers to embrace atheism. The task that the Stoics undertook was not only to pinpoint the deficiencies of traditional mythology and religion, but also to rectify them. This rectification consisted in such a reinterpretation of the Pantheon of the Greek gods that all these deities transpired to be self-externalizations of one pantheistic God. Apart from all the afore-cited testimonies, we find this idea also in the De natura deorum: when rejecting the traditional myths, Balbus recognizes a God that "permeates nature" (deus pertinens per naturam) and illustrates the idea with "Ceres pervading the earth" (per terras Ceres), "Neptune pervading the sea" (per maria Neptunus), and so on. ${ }^{22}$ Balbus' testimony nicely accords with all the other sources that have been discussed above: man is surrounded by diverse manifestations of the World Soul, the distinct names of the anthropomorphic gods and goddesses are merely the expressions of this God-Pneuma, and etymology is precisely the key to understanding the divinity of the God-Cosmos.

\footnotetext{
90 Cic., De nat. d. II, 70.

91 SVF II, 1076.

92 Cic., De nat. d. II, 71.
} 
Without the aid of etymological and/or allegorical interpretations, religion is doomed to naïve and immoral anthropomorphism. On the other hand, studying meticulously the customarily religious nomenclature leads to a genuinely sacred reality. That is why studying the traditional names of all deities is for the Stoics not pointless but pious. Etymology is what transforms mythology and religion from shallow literalism to a profound religious experience. As a matter of fact, the Stoics suggest that to refrain from transcending the manifest and superficial dimension of conventional religion is tantamount to failing as a worshipper and, thus, becoming guilty of blasphemy. That is why Balbus so forcefully contrasts superstitio with religio, ${ }^{93}$ whereas Cornutus with equal vehemence differentiates between "piety" (

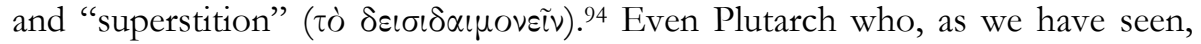
can be very critical of Stoic etymologizing, praises in his On Isis and Osiris, this type of pious hermeneutics that leads to "having true opinion about the gods"

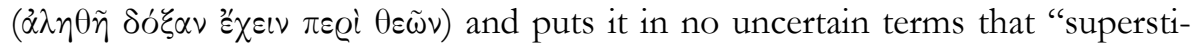

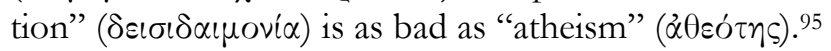

For Balbus, Cornutus and Plutarch, as for the early Stoics, an appropriate etymological and/or allegorical interpretation makes it possible to liberate religion from superstition. That is why the Stoics attribute an existential dimension to their etymologizing: through etymology we discover God (whether He be called Logos, Pneuma or Zeus) and through God we discover ourselves. This discovery results in a transformation of our lives, for to understand God is to live in accord

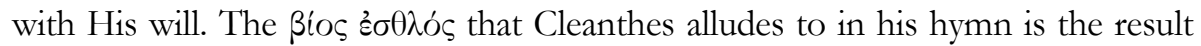
of implementing what one has apprehended: etymology provides us with the possibility of knowing God, applying this knowledge and, thereby, changing our lives. Needless to say such a noble life and such genuine religiousness are available only for a Stoic sage.

\section{Conclusions}

Let us recapitulate. Etymology is an integral part of Stoic theology, since etymologizing the names of the conventional gods becomes for the philosophers an encounter with God through language. The Stoics' pantheistic, hylozoistic, vitalistic and organicistic view of the cosmos makes it natural for the thinkers to use etymology as a tool for deciphering the diverse manifestations of God. Consequently, etymology becomes in Stoicism not so much the study of the history of words, but rather the study of how God makes Himself known to us in the various phenomena of our world. Inasmuch as God is here

\footnotetext{
93 Cic., De nat. d. II, 71-72.

94 Corn., 76, 12-13.

95 Plu., De Is. et Os., 355c-d.
} 
a creative force that permeates the universe and assumes distinct appellations in correspondence with its numerous powers, the particular names of the traditional gods and goddesses transpire to be no other than expressions of one and the same Divinity. Hence, the Pantheon of the Greek gods proves to be a self-externalization of the Stoics' pantheistic Deity.

The Stoic understanding of etymology as the study of God's diverse manifestations prompts the philosophers to implicitly differentiate between two ways of describing Divinity. The philosophical understanding of God makes use of such abstract terms as Logos, Pneuma, Providence, etc., whereas the folk conception of Divinity resorts to such contingent names as Zeus, Hera, Hephaestus, and so on. Importantly, from a Stoic perspective both terminologies turn out to be two sides of the same coin. Thus, the philosophers do not discard conventional mythology. Neither do they opt for abrogating traditional religion (although their characterizing God as anima mundi is evidently tantamount to denying the personality of God). Rather, the Stoics employ etymology to make the existing mythology and religion truly relevant and meaningful. Their etymologizing is supposed to pave the way for genuine religiousness and authentic piety, for inasmuch as studying the names of the gods is identical with discovering God, etymology becomes in Stoicism a tool for honouring God and, at the same time, for transforming one's existence.

Adam Mickiewicz University

Mikolaj DOMARADZKI

Szamarzewskiego 89 C

PL - 60-569 POZNAN

E-mail:mikdom@amu.edu.pl 